\title{
Analysis on the Construction of Curriculum and Teaching Staff for the Business English Major
}

\author{
Shaowei Li \\ Zaozhuang University \\ Zaozhuang Shandong, China \\ 277160
}

\begin{abstract}
The globalization of world politics, culture and economy has made cross-cultural communication more and more frequent among countries. The communication model of the globalization has increased the demand for business English majors, and the specialized training of the talents has been improved. Business English majors should not only have professional English language skills, but also have relevant business professional knowledge and professional skills in order to become professional talents with compound abilities. New challenges are brought to the curriculum construction and the construction of teaching staff in China's universities. This paper will focus on the key issues of how to adapt to the current development and how to improve the training of business English majors.
\end{abstract}

Keywords-Business English; Curriculum construction; Teaching staff

\section{INTRODUCTION}

As a common language of international trade, English is widely used in business. As the globalization of economy and trade, China has more deeply involved into the broader international business activities. The social demand for talents with business English professional skills is rising, so the colleges cultivating the business English majors face higher request. For the college business English majors, it is not enough to have solid English language knowledge and strong ability of English application; they should master broad knowledge of business and business operation ability, and be able to skillfully use business English to complete business activities. The complexity and applicability of the knowledge of business English professions require the complex and practical ability of teachers. At present, China's institutions of business English majors face great challenges. The graduates are poor in professional ability and are not apt to undertake the practical work. The main reason is the professional teachers' situation and professional curriculum construction which are insufficient to meet the needs of the business English teaching. Therefore, how to build an effective professional curriculum of business English is a problem to be solved and the construction of the teaching staff is the most difficult part of it.

The 12th national conference on international business English was held in October 2016, the theme of this conference is "the innovation and development of business English subject construction and business English". The representatives launched a discussion on the theory construction of business English, the national implementary standards and the corresponding measures of business English, business English specialty construction and the cooperation between colleges and companies, business English teaching materials research, English teachers' professional development.The meeting pointed out the direction for the further development of business English majors in our country, and provided guidelines for further transformation of the construction of college English from the general English teaching to the business English teaching , and raised further thinking of business English professional training, training mode, teachers construction, teaching methods and other issues . Representatives of the conference held a speech on topics such as the international standards of business English and the business English ontology. The experts pointed out the problems and opportunities of business English in the new situation of the trade between China and other countries. Therefore, in the process of economic globalization, we face the problems such as the unclear teaching aims, imperfect curriculum and the simple teaching methods. It is urgent to cultivate teaching staff with high quality and to strengthen the curriculum construction.

\section{CHARACTERISTICS OF BUSINESS ENGLISH AND THE ORIENTATION OF THIS DISCIPLINE}

The discipline is the basic platform for the cultivation of talents, academic research and social services. From the perspective of higher education, the discipline refers to a certain scientific field or a branch of science, which has a systematic, relatively complete and independent theoretical system. The discipline is the basis of the profession, and the discipline level is the mark that measures the level of school education. [1] From the explanation to the definition of discipline, we know that business English subject should be guided by linguistics and applied linguistics, involved in many categories and interdisciplinary subjects, namely it combines English language skills and business expertise. Nick Brieger, a British business English specialist, points out that business English should include language knowledge, communication skills, professional content, management skills and cultural awareness. The other professional knowledge includes economy, trade, finance, law, tourism, environmental protection, enterprise operation and management, press and publication, culture and education industry, high-tech industry, etc. 
The domestic academic community has a quite different orientation for business English. Most scholars agree that business English is a branch of ESP (English for Specific Purposes), its representative is Professor Wang Xingsun who thinks "Business English is the English which is actually applied in English business environment." [2] ESP is English that is associated with a particular profession or purpose. Some scholars generalize that it has at least two characteristics: Firstly, it has a clear purpose, or to be applied in certain professional fields; Secondly, there is special content that relates to specialized knowledge or field. In this sense, business English is ESP for the students who are already engaged in or will be engaged in the business field. It has many unique linguistic phenomena, including vocabulary, language, structure, style, etc. which require special training. Some traditional scholars believe that English can be used as business English in foreign trade. So before the 1980s, business English was known as foreign trade English. Some scholars have also given the new concept of its orientation, which is that business English is the application of English in international business in the guidance of foreign linguistics and applied linguistics. Therefore, business English is a discipline of including both linguistics and economics. From these orientations, it is not difficult to find that the different perspectives of the orientation of business English study reflect the deepening of academic research on business English subject. Business English is an independent language category, with rich connotations and extensive areas. Business English education activity is mutual, interdependent and inseparable. This gives the business English more extensive subject localization and disciplinary connotation.

With the increasing political, economic and cultural exchanges between China and the world, English as a language tool has been mastered by more and more people. As Widdowson points out, "learning English is just an aid to other professional or academic uses of English for the non-native learners." Due to the particularity of its language and professional knowledge, it is no longer suitable for learners of business English to master foreign language knowledge and basic skills. As Liao Ying notes: English language and literature major can't meet the needs of the times. Contemporary linguistics can not replace the role of ESP in social communication and in improving teaching methods; to improve the ability of understanding of the language itself is not enough to master English of a certain field, because it involves many relevant discipline knowledge. It is important to treat English (including some languages) as a tool that can only be combined with a certain profession to form professional English. Therefore, the concept of business English learning should be constantly updated and separated from the traditional and single language learning, so as to combine the skills with the practice of skills. Meanwhile, the concept of keeping abreast with the times must be closely followed in the construction of business English curriculum.

Curriculum construction is the whole and fundamental problem of education and education. It is not only the education idea, education principles, the concentrated reflection of the education content, but also the implement of the education policy, the main form and way to carry out the training objectives, to improve the quality of education. It plays an important role in cultivating the students' comprehensive quality. Currently curriculum has narrow and broad definition. The generalized understanding of it refers to the guidance to lead students to acquire knowledge. It is composed of course objectives, course content, curriculum structure, course teaching hours, curriculum teaching schedule and other elements. Curriculum construction includes course structure and single-course construction. To evaluate the course construction we should follow the principle of objectivity, unity and comprehension, and we should pay attention to the different characteristics of the hardware construction and software construction, and the necessity of participating in the construction by students, feasibility and scientific aspects of the curriculum construction evaluation problems, and the differences between different colleges and universities. $^{[3]}$

At present, with the change of the economic growth mode and the change of industrial structure and accelerating globalization, large enterprises and other business groups for business English major students put forward higher requirements. Firstly, students should have good communication skills and can use foreign language fluently. Secondly, students should have solid business knowledge and can combine theory with practice. Thirdly, strong comprehensive ability is also a necessary quality for students majoring in business English. Teaching more than 30 years, currently at Valencia in Spain, the lid of the British embassy, Mr. Brooke hart said: "Business English itself has a distinct discipline characteristic, the development of its education and research should be combined with the context of globalization, it should give the agile accurate answers." But with the current situation in China, the traditional English teaching only pays attention to the development of language skills. English is taught on the basis of English teaching model in combination with business common sense, a single classroom teaching mode, adopting the traditional method that is teacher-speaking, student- listening which is a unidirectional mode. English teachers of business English major lack global culture consciousness, not to put business English learning in a real business situation, not lecture the necessary cultural knowledge in the classroom teaching, resulting in the emphasis on language and commerce, the neglect of ability and culture. Business English teaching reflects the absence of culture teaching from the syllabus, curriculum arrangement, textbooks, exams and teaching methods. This makes it necessary to reconstruct or adjust the curriculum, content and teaching methods of college business English majors. How to choose from the huge curriculum system and to reconstruct effective characteristics of the curriculum system is the key to determine the healthy development of college business English majors.

The quality and training of teachers in business English are the key factors, especially the training goal and approach of compound teachers. This is a concern for many teachers in business English teaching post. A business English teacher can be an expert in a certain business field, but it is a better result if he can be a composite of foreign language and business disciplines. There is a lot of tacit knowledge in business 
discourse. Not understanding the business which not only refers to the subject knowledge, but also includes industry operating practices, procedures, and knowledge), teachers may be insensitive to the business discourse knowledge in the process of work, and can't really inspire the student to consider a problem from the angle of complete business activities. At present, most of business English professional teachers in colleges and universities belong to teachers graduating in English major, and fewer teachers are with the enterprise or industry background. They have long engaged in English teaching with profound English knowledge and flexible teaching skill. But most of them are not trained in a system of business knowledge, lack of relevant enterprises working experience and background knowledge. They have less understanding about the future jobs for students, so they can't give students good demonstration and guidance in business practice teaching process. The new teachers have a systematic theory of English knowledge and skills, high work enthusiasm, good communication ability with the students, and are familiar with network, multimedia and other modern teaching means. They are the main forces of professional development, but because of a shortage of experience in teaching, the lack of professional practice experience and relevant industry knowledge and skills, they need to be trained and improved in English education, professional practice and industry knowledge. The teachers introduced from the enterprises and companies have a wealth of practical experience, a higher level of practical and profound professional theory, understand the operation mode of enterprises, and are closely associated with the enterprises, are the backbone of the construction of practical teaching and practical training base construction, but they are lack of education teaching theory, and teaching methods, and their teaching means are slightly single. They need to improve their basic teaching quality and teaching skills, and their education theory study and practice should be strengthened. Part-time teachers recruited from outside schools are a complementary force for professional development. These part-time teachers work in the business practice for a long time, have skilled business skills and extensive industry background knowledge, are familiar with the industry in product information, market trends, business operation and development trends, understand the quality requirements of the industry professionals, can arrange or help arrange students to enterprises, and the relevant departments for training. But this kind of the teachers are business elite for the enterprise who are busy. It is difficult for them to be deeply involved in the daily teaching work, to participate in the professional construction and practice teaching only in the form of lectures and practice guidance. In conclusion, the current business English teachers have caused professional limitations due to their study and work experience. The excellent teachers for business English with profound and solid professional knowledge are very few. The teachers with many theories are more, and the teachers who are good at practice guidance are insufficient; there are few teachers with master's degree or higher degrees, but most of them are young teachers lacking theoretical and practical teaching experience. So the teacher structure has not formed a good echelon. Therefore, it is difficult for such a professional team to fully meet the needs of teaching, and it is difficult to cultivate highly qualified and skilled English talents who are badly needed in the job market. Thus, only by building a highquality teachers team, the business English teaching in China can catch up with the world advanced level in teaching contents, teaching methods, teaching effect and teaching research, etc. Nowadays, colleges and universities have realized the necessity and urgency of building high-quality teachers in the development of business English majors. ${ }^{[4]}$

\section{THE TASK OF THE CONSTRUCTION OF CURRICULUM AND TEACHING STAFF FOR THE UNIVERSITY BUSINESS ENGLISH MAJOR}

In the new century, in an emerging field of English teaching China's business English teaching and personnel training must have greater development. We are faced with urgent and important tasks in teaching staff construction and course construction.

On the basis of the scientific curriculum theories, Taylor's the Basic Principles of Curriculum and Teaching and the latest achievements of modern foreign language teaching research preliminary established the business English professional curriculum construction mode, namely "the English using ability is the core with full-time industry as the background, and supported by the international trade capacity, and to practice ability training as the main guideline”. We should cultivate students with strong English language application ability, to understand the production and business operation process and related products technical standards, and to master the knowledge and skills of international trade of higher English talents. In the national symposium on international business English, President of China society of international business English, foreign economic and trade university President, professor Chen Zhunmin said: "business English education in the meet of the application requirements under the market economy system, still should not give up the humanistic care education concept and solid professional English language education. Students should not be lost in "quality education." Therefore, in the professional course system of business English, we should join the curriculum of humanistic quality and reform the evaluation system. Pay attention to the cultivation of students' ability in excitation and diffusion ability, the cultivation of their active, independent and cooperative ability in work and study, so that the students can get all-round development in the humanities, innovation thinking, interpersonal communication and cooperation spirit. In the guidance of the professional industry we should in the curriculum building, analyze the business English major students' ability to job requirements and related jobs in different task, select the theoretical knowledge and practical means of integrating theoretical knowledge and practical knowledge, change the wrong understanding that practice is to extend the theory, train the student to focus on the completion of tasks of work rather than the memory of knowledge , make the students experience the fun of work task in the process of learning. As head of the department of Shanghai maritime university, professor of business English in foreign languages institute, Weng FengXiang thought: “business English course is to balance the relationship between English language and business. Business English discipline is easy to focus on 
practical empirical research, but in fact, theoretical research cannot be ignored, because only theory can guide practice. The process of guiding practice is actually a test of the theory." [5]

To cultivate highly qualified business English talents with professional knowledge, we must have a high quality professional teaching team. Teachers who are engaged in business English teaching must have strong teaching ability, teaching reform and research ability, practical guidance ability and certain professional practical experience. Teachers should strengthen their professional knowledge and improve their professional knowledge and business level, the schools also should actively encourage teachers to study in various ways which are suitable for them: (1) Take part in training out of campus. Teachers should be encouraged to take part-time courses, and teachers can participate in teachers' training courses organized by domestic authoritative institutions. (2) Encourage young teachers to study for a master's degree in business English with some preferential policies. (3) Recruit high-quality business professional foreign teachers and enrich the teaching staff. (4) Some schools adopt the method of introducing overseas returnees or sending teachers who teach specialized courses to foreign countries for short-term language training. These teachers who returned from overseas, masters, and doctors have solid language foundation of basic skills, overseas learning experience, the advanced foreign education idea, education methods and advanced knowledge. They are the indispensable talent in the process of education internationalization. (5) Cooperate with other schools. By introducing, grafting, and cooperation with foreign universities in holding international business English course, we can improve business English teaching and research, and understand the English teaching and research development, the curriculum, teaching methods in the English countries. In particular, for learning their curriculum and teaching organization embody the advanced education concept, we can also send teachers to foreign universities for further study. In the domestic teaching, we will prepare lessons together with foreign teachers, study teaching programs, and organize seminars. In this way, it is advantageous to form an advanced teaching team with adopting advanced teaching method and teaching method who can teach English national business English course. (6) Hire companies' successful personage as guest teachers to give lectures to enrich the business English professional teaching staff, then students can further understand the latest development of the industry. We should strengthen the professional atmosphere, strengthen the student's professional ideas, and supplement their professional knowledge.

In teaching, cultivating students' business communication ability is the core of business English majors. However, most of our business communication education is still guided by the western traditional intercultural communication theory and not separated from the rigid education training. And through the above review and analysis, it is not enough to ensure the effective communication of transnational business only to understand emotions, social culture and subjective values. We have to understand the corporate culture, professional culture and individual differences of the communicative partners. And these integrative factors can be dynamic that occur in the workplace. And to understand all of them, it is very difficult to achieve through a textbook and a course. We have to cultivate qualified cross-cultural business communicative talents. The comparison system should be established through scientific argumentation and we should elaborately design a group of three-dimensional business communication courses. The group covers cross-cultural, business and communication levels content. And teachers should teach through theory and practice, and actively guide students to realize the impact of business communication. The dynamic construction of factors promotes them to be more dialectical and sensitive. This kind of curriculum group construction would be suitable for our overall training goals of business English major. ${ }^{[6]}$ The emphasis on curriculum building and teacher training would play an important role in cultivating the cross-cultural business communication talents in China.

\section{CONCLUSION}

Above all, in the 21st century universities will play an important role in the development of knowledge economy. Universities will be more important in the knowledge economy society. Knowledge society provides unprecedented opportunities for development of university and social demand for university opens up broad prospects for the development of universities. China's foreign economy also presents an multidirectional, multilevel and wide-range situation which provides valuable opportunities to students who can master English, especially those who are proficient in business English, at the same time, it poses challenges to the traditional system of English talents cultivation. Therefore, scientific subject orientation, complete course construction and the effective construction of teachers team provide a solid foundation for the development of business English in college, and they can provide a powerful guarantee for the education and cultivation of the business English talents. Universities should fully realize the importance of the construction of the business English professional teaching staff and the importance of the curriculum construction. We should cultivate talents who can meet the demand of the economic globalization, having strong English application ability and mastering the knowledge of international business.

\section{REFERENCES}

[1] Song Xiaoping, Lu Shuyun. Related concepts of discipline, Education Research of Tsinghua University, 2004 (6)

[2] Cheng Shilu, Zhang Guoyang. Theory and practice of ESP. Guangxi Education Press, 1996.

[3] Hao Deyong. Methodology of curriculum development. Beijing, Education Science Press.,2000.

[4] Zhong Qiquan. Modern curriculum theory. Shanghai: Shanghai Education Publishing House, 1989.

[5] Chen Li, Special Purpose English study. Shanghai, Fudan University Press, 2000

[6] [6]Gudykunst, W. Bridging Difference: Effective Intergroup Communication[M]. London: Sage, 2004. 